\title{
A nalysis of rainfall data for storage and irrigation planning in humid south-eastern plain of Rajasthan in India
}

\author{
Bhim Singh $^{1 *}$, C.K. Arya ${ }^{1}$, J itendra Singh ${ }^{1}$ and K.K. M ourya ${ }^{2}$ \\ ${ }^{1}$ College of Horticulture and forestry, Jhalarapatan, Jhalawar-326023 (Rajasthan), INDIA \\ ${ }^{2}$ Department of Agricultural Statistics, NDUAT, Faizabad-224229 (U.P.), INDIA \\ *Corresponding author. E-mail: bhimsinghl@gmail.com
}

Received: M arch 23, 2014; Revised received: M ay 16, 2014; Accepted: M ay 25, 2014

Abstract: A study was carried out to analyze the rainfall data for storage and irrigation planning under humid south-eastern region of Rajasthan using a time series record for 32-year (1980-2011) periods. It was observed that most of the years under observation were having adequate rainfall for all round the year crop production provided the water were collected during the rainy season. The area received $921.5 \mathrm{~mm}$ annual rainfall out of which $92 \%$ occurred during southwest monsoon (June-September) season. Of the total study period of 32 years, $19 \%$ were drought years, $66 \%$ were normal years and the remaining $15 \%$ were the abnormal years. The annual rainfall during the period showed negative trend $(-6.955 \mathrm{~mm} /$ year). It showed decreasing trend $(-7.782 \mathrm{~mm} /$ year) during the month of August and positive trends with $0.864,3.909$ and $1.192 \mathrm{~mm} /$ year, respectively, during month of June, July and September. The analysis generally showed that water deficit appeared during the period of November up till May and rain water was excess during the period of June up till September. During these months, rain water can be stored with the help of rainfall harvesting system. If only $50 \%$ of total rain water is collected, it forms approximately 44.16 lacs litres of water on a unit hectare basis of land. This rainfall water will be adequate for all rounds the year crop production with conservation of rain water and judicious use of rain water resources.

Keywords: Abnormal, Drought, Irrigation planning, Normal, Rainfall, Storage

\section{INTRODUCTION}

The amount and distribution of rainfall in any particular area are very helpful in sound crop planning (Singh and Sharma, 2003). The average rainfall of the region is generally considered as the basis for deciding irrigation management and cropping pattern. But, it is has been observed that the knowledge of mean annual rainfall may not be that much useful to decide irrigation and water management activities for crop production. Long term analysis is vital for firm planning and execution of crop cultivation. Various authors have analysed rainfall data for crop planning and irrigation management. Momin et al. (2011) analyzed the distribution of rainfall characteristics for better planning in rainfed farming system. Several workers viz. Bhakar et al. (2008), Sheoran et al. (2008), Rai and Singh (2009), Singh et al. (2009), Solanki and Singh (2009), Srivastava and Shukla (2009), Upadhyay and Upadhyay (2009), Singh and Dev (2012) and Singh et al. (2012) have studied the rainfall analysis in relation to crop planning. Further, in view of deepening water crisis almost across the globe, water harvesting has been much sought after aspect for offering at least life saving supplemental irrigation to crop plants. In this context, rainfall becomes a matter of significant importance especially for planning and designing structures for rainwater harvesting (Murty, 1994) to feed the water requirement of crops. The rainfall distribution in India is most uneven and varies considerably from region to region and from year to year. Therefore, a study was carried out to analyze the pattern of rainfall for irrigation planning and management specific to humid south-eastern region of Rajasthan. Monthly estimation of rainfall data for assessment of normal years, abnormal years, drought years, normal months, abnormal months, and drought months has been made which is expected to be useful from the view point of cropping pattern, irrigation planning and management.

\section{MATERIALS AND METHODS}

The study pertains to humid south-eastern plain under Zone $\mathrm{V}$ of the Rajasthan which covers an area of about 2.7 million ha and represents 7.8 per cent area of the state. It consists of four districts - Kota, Bundi, Baran and Jhalawar. This region is commonly known as $\mathrm{H}$ adauti region, the land of $\mathrm{H}$ adas. Chambal is the main river along with its main tributaries like Parvati, Kali Sindh, Parwan and Banas. The region has the expansion of fertile black soils with natural vegetation in the form of woodlands, parklands and open forests though degraded. The annual rainfall ranges between $650 \mathrm{~mm}$ in north-west to $1100 \mathrm{~mm}$ in South-east. High rainfall along with rich soils provides adequate support to the agriculture in the region. Daily rainfall data of Jhalarapatan station $\left(24^{0} 33^{\prime} \mathrm{N}\right.$ and $\left.76^{\circ} 10^{\prime} \mathrm{E}\right)$ have been used for the present investigation. A time series of rainfall record for the period of 32 years 
Table 1. Annual drought analysis in the study area.

\begin{tabular}{|c|c|c|c|c|}
\hline Y ear & $\begin{array}{c}\text { Rainfall } \\
(\mathrm{mm})\end{array}$ & $\mathrm{SD}(\mathrm{S})$ & Skewness & Category \\
\hline 1980 & 454.9 & 74.45 & 2.14 & $\mathrm{D}$ \\
\hline 1981 & 714.1 & 87.10 & 1.54 & $\mathrm{~N}$ \\
\hline 1982 & 1207.8 & 187.48 & 2.24 & $\mathrm{~N}$ \\
\hline 1983 & 920.2 & 120.19 & 1.70 & $\mathrm{~N}$ \\
\hline 1984 & 1082.6 & 181.78 & 2.67 & $\mathrm{~N}$ \\
\hline 1985 & 1331.2 & 203.29 & 2.61 & A \\
\hline 1986 & 1890.8 & 342.69 & 2.66 & A \\
\hline 1987 & 1247.7 & 205.08 & 2.95 & A \\
\hline 1988 & 955.6 & 123.69 & 1.40 & $\mathrm{~N}$ \\
\hline 1989 & 478.8 & 94.06 & 3.11 & D \\
\hline 1990 & 792.9 & 124.62 & 1.77 & $\mathrm{~N}$ \\
\hline 1991 & 741.0 & 136.23 & 2.07 & $\mathrm{~N}$ \\
\hline 1992 & 869.0 & 122.32 & 2.14 & $\mathrm{~N}$ \\
\hline 1993 & 943.8 & 116.39 & 0.96 & $\mathrm{~N}$ \\
\hline 1994 & 914.8 & 124.70 & 1.51 & $\mathrm{~N}$ \\
\hline 1995 & 828.2 & 110.77 & 1.67 & $\mathrm{~N}$ \\
\hline 1996 & 1247.8 & 194.06 & 2.04 & A \\
\hline 1997 & 1168.2 & 99.40 & 0.74 & $\mathrm{~N}$ \\
\hline 1998 & 594.3 & 65.30 & 1.04 & D \\
\hline 1999 & 1205.8 & 168.22 & 2.14 & $\mathrm{~N}$ \\
\hline 2000 & 655.2 & 125.74 & 3.10 & $\mathrm{~N}$ \\
\hline 2001 & 924.6 & 162.85 & 2.60 & $\mathrm{~N}$ \\
\hline 2002 & 559.8 & 90.26 & 2.47 & $\mathrm{D}$ \\
\hline 2003 & 935.2 & 115.80 & 1.05 & $\mathrm{~N}$ \\
\hline 2004 & 929.2 & 162.28 & 2.25 & $\mathrm{~N}$ \\
\hline 2005 & 743.0 & 131.93 & 2.85 & $\mathrm{~N}$ \\
\hline 2006 & 1560.2 & 244.92 & 2.67 & A \\
\hline 2007 & 497.4 & 66.12 & 1.53 & $\mathrm{D}$ \\
\hline 2008 & 636.0 & 83.18 & 1.59 & $\mathrm{~N}$ \\
\hline 2009 & 834.0 & 145.84 & 3.01 & $\mathrm{~N}$ \\
\hline 2010 & 524.6 & 62.83 & 1.17 & $\mathrm{D}$ \\
\hline 2011 & 1099.4 & 141.75 & 1.42 & $\mathrm{~N}$ \\
\hline
\end{tabular}

(1980-2011) have been collected from Water Resource Department, Government of Rajasthan, Sinchai Bhawan, Jaipur. Daily rainfall data was converted on monthly basis to estimate normal months, abnormal months and drought months. Yearly analysis has also been done to estimate the normal years, abnormal years and drought years. The criteria as used by Sharma et al. (1979) were adopted for computing drought. Any month receiving rainfall less than $50 \%$ of the average monthly rainfall has been taken as drought months; between $50 \%$ and $200 \%$ of the average monthly rainfall as normal month and that receiving rainfall more than twice of the average monthly rainfall as wet month. Also, if $\mathrm{X}$ is the mean annual rainfall and $\mathrm{S}$ is the standard deviation, then a year has been counted under drought, normal and wet if it receives rainfall less than $\mathrm{X}-\mathrm{S}$, in the interval $[\mathrm{X}-\mathrm{S}, \mathrm{X}+\mathrm{S}]$ and more than $X+S$, respectively (Bora et al., 2008).

The Mann-Kendall trend test (Mann 1945; Kendall 1975) has been used to analyze the trends of rainfall. Details of Mann-Kendall test can be obtained in Sneyers (1992). Some trends may not be evaluated to be statistically significant while they might be of practical interest (Basistha et al., 2007). In the present
Table 2. Annual and monthly rainfall trend in the study area (Q-Sen's Slope).

\begin{tabular}{lcc}
\hline M onth/Y ear & M -K test & $\begin{array}{l}\text { Trend (Q) } \\
\text { (mm/year) }\end{array}$ \\
\hline June & 0.859 & 0.864 \\
July & 1.119 & 3.907 \\
August & $-2.108^{*}$ & -7.782 \\
September & 0.714 & 1.192 \\
October & -1.641 & 0.000 \\
November & 0.000 & 0.000 \\
December & 0.000 & 0.000 \\
January & -0.882 & 0.000 \\
February & -0.555 & 0.000 \\
March & 0.000 & 0.000 \\
April & -0.123 & 0.000 \\
May & -0.738 & 0.000 \\
Annual & -0.957 & -6.955 \\
\hline
\end{tabular}

*Significant at 0.05 level

study, linear trend analysis was also carried out and the magnitude of trend is estimated by Sen's Slope method (Sen, 1968). Sen's Slope method gives a robust estimation of trend (Yue et al., 2002). Sen's method calculates the slope as a change in measurement per change in time.

\section{RESULTS AND DISCUSSION}

From the analysis of data for the period of 32 years (1980 to 2011), the average annual rainfall of Jhalarapatan station appeared as $921.50 \mathrm{~mm}$ with a standard deviation of $326.07 \mathrm{~mm}$ and a coefficient of variation of 35.38 percent. Hence, the years receiving rainfall less than $595.43 \mathrm{~mm}$ can be term as drought (D) years, more than $1247.57 \mathrm{~mm}$ as abnormal (A) years and these between $595.43 \mathrm{~mm}$ and $1247.57 \mathrm{~mm}$ as the normal $(\mathrm{N})$ years. Standard deviation varied from $62.83 \mathrm{~mm}$ to $342.69 \mathrm{~mm}$. Coefficient of skewness varied from 0.74 to 3.11 . For analysis of normal, abnormal and draught months the average monthly value of mean and standard deviation are presented in Table 1. Of the total study period of 32 years, 6 years (19\%) i.e. 1980, 1989, 1998, 2002, 2007 and 2010 were drought years; 21 years $(66 \%)$ i.e. 1981, $82,83,84,88,90,91,92,93,94,95,97,99,2000$, 2001, 2003, 2004, 2005, 2008, 2009 and 2011 were normal years and the remaining 5 years $(15 \%)$ i.e. 1985, 86, 87, 96 and 2006 were the abnormal years. The seasonal distribution of rainfall was also computed. The monsoon (June-September) season had contribution of $93 \%$ of total annual rainfall in the region (Fig. 1).

During the period 1980-2011, annual rainfall showed negative trend $(-6.955 \mathrm{~mm} / \mathrm{year})$ in the study area (Table 2). The rainfall showed decreasing trend (-7.782 mm/year) during the month of August which was statistically significant at 0.05 level of significance. It showed positive trends i.e. 0.864, 3.909 and $1.192 \mathrm{~mm} /$ year, respectively, during month of June, July and September but they were statistically not significant. The rainfall values for normal, abnormal 


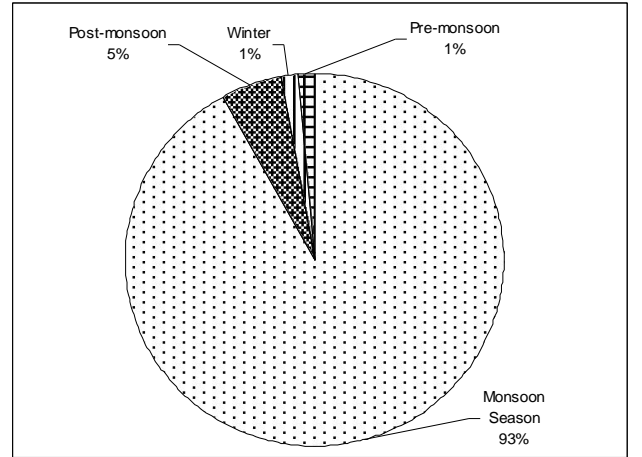

Fig. 1. Seasonal distribution of rainfall.

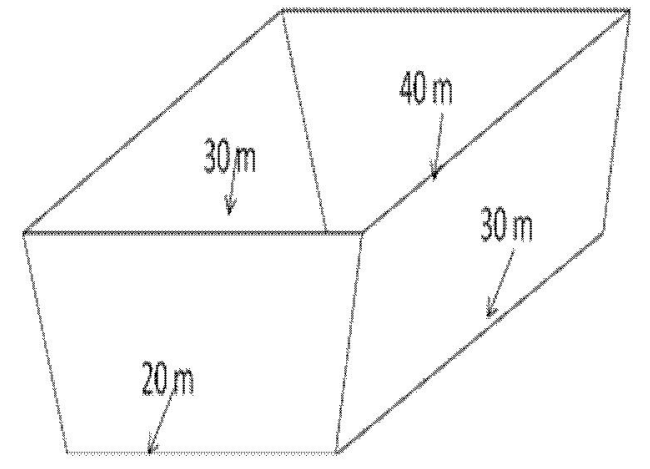

Fig. 2. Structural dimension of trapezoidal shape of pond.

Table 3. The amount of rainfall ( $\mathrm{mm}$ ) for abnormal or normal classification.

\begin{tabular}{lcccc}
\hline M onth & A ver age rainfall & $\begin{array}{c}\text { Drought } \\
\text { (less than) }\end{array}$ & $\begin{array}{c}\text { Abnormal } \\
\text { (more than })\end{array}$ & $\begin{array}{c}\text { Normal } \\
\text { (R ange between) }\end{array}$ \\
\hline June & 89.65 & 44.83 & 179.30 & $44.83-179.30$ \\
July & 294.98 & 147.49 & 589.97 & $147.49-589.97$ \\
August & 345.57 & 172.78 & 691.13 & $172.78-691.13$ \\
September & 116.32 & 58.16 & 232.64 & $58.16-232.64$ \\
October & 28.88 & 14.44 & 57.75 & $14.44-57.75$ \\
November & 14.06 & 7.03 & 28.11 & $7.03-28.11$ \\
December & 5.77 & 2.88 & 11.54 & $2.88-11.54$ \\
January & 6.32 & 3.16 & 12.63 & $3.16-12.63$ \\
February & 6.69 & 3.34 & 13.38 & $3.34-13.38$ \\
March & 3.48 & 1.74 & 6.95 & $1.74-6.95$ \\
April & 3.04 & 1.52 & 6.09 & $1.52-6.09$ \\
May & 6.76 & 3.38 & 13.52 & $3.38-13.52$ \\
Annual & 921.5 & 595.43 & 1247.57 & $595.43-1247.57$ \\
\hline
\end{tabular}

Table 4. Decadal shift in rainfall $(\mathrm{mm})$ pattern in the study

\begin{tabular}{lcccc}
\hline M onth/Period & $1980-89$ & $1990-99$ & $2000-09$ & $2010-11$ \\
\hline June & 90.28 & 77.48 & 100.24 & 94.40 \\
July & 279.89 & 299.59 & 320.24 & 221.15 \\
August & 452.15 & 320.77 & 276.22 & 283.35 \\
September & 102.35 & 142.98 & 92.84 & 170.30 \\
October & 56.90 & 26.90 & 8.60 & 0.00 \\
November & 17.52 & 17.26 & 7.10 & 15.50 \\
December & 3.60 & 13.40 & 1.46 & 0.00 \\
January & 6.87 & 8.02 & 0.62 & 23.50 \\
February & 5.66 & 10.64 & 5.10 & 0.00 \\
March & 0.00 & 4.28 & 6.84 & 0.00 \\
April & 3.10 & 5.56 & 1.08 & 0.00 \\
May & 10.05 & 3.70 & 7.12 & 3.80 \\
Annual & 1028.37 & 930.58 & 827.46 & 812.00 \\
\hline
\end{tabular}

and drought with average were estimated (Table 3 ). Maximum mean monthly rainfall in the region varied from $3.04 \mathrm{~mm}$ in the month of April to $345.57 \mathrm{~mm}$ in the month of August. Monthly mean values were found to be $76.79 \mathrm{~mm}$. There is a large variability among the monthly values of rainfall for different years. The coefficient of variation varies from 0.578 in the month of August to 3.045 in the month of December. Variance is maximum during June-September. It indicates atmospheric instability during monsoon season. The minimum value of standard deviation was observed 6.88 during April. It indicates better weather stability during month of April. A decrease trend in decadal average rainfall has been observed during past 32 years. The highest average rainfall of $1028.37 \mathrm{~mm}$ was recorded during the decade (1980-89) and the lowest average rainfall of $712.00 \mathrm{~mm}$ was received during 2010-11 (Table 4). The data as regard to normal, abnormal and draught months are presented in table 5. It indicates that the sufficient rainfall appeared during the month of June-September and most water deficit occurred during the months of November till May. Hence, the monsoon season was observed as normal. During these months storage of rains water can be done for irrigation purpose. Therefore, there is need for water storage systems for irrigation planning and manage- 
Table 5. Monthly drought, normal and abnormal period in respective years.

\begin{tabular}{|c|c|c|c|}
\hline Y ear & Drought & Normal & Abnormal \\
\hline 1980 & July, Sep, Oct, Nov, Jan, Feb, Mar, Apr, May & June, Aug & Dec \\
\hline 1981 & June, Dec, Jan, Feb, Mar, Apr & July, Aug, Sep, Oct, May & Nov \\
\hline 1982 & June, Sep, Dec, Feb, Mar & July, Aug, Oct, May & Nov, Apr, \\
\hline 1983 & July, Nov, Dec, Jan, Feb, Mar & June, Aug & Sep, Oct, Apr, May \\
\hline 1984 & Oct, Nov, Dec, Feb, Mar, Apr, May & June, July, Aug, Sep, Jan & \\
\hline 1985 & June, Nov, Dec, Jan, Feb, Mar, Apr & July, Sep & Aug, Oct, May \\
\hline 1986 & Sep, Oct, Nov, Dec, Mar, Apr & June, Aug, Jan & July, Feb, , May \\
\hline 1987 & June, July, Nov, Mar, Apr & Sep, Feb, May & Aug, Oct, Dec, Jan \\
\hline 1988 & Nov, Dec, Jan, Feb, Mar, Apr, May & July, Aug, Sep, Oct & June \\
\hline 1989 & July, Sep, Oct, Nov, Dec, Jan, Feb, Mar, Apr, May & June, Aug & \\
\hline 1990 & June, Oct, Nov, Dec, Jan, Mar, Apr, May & July, Aug, Sep, Feb & \\
\hline 1991 & June, Sep, Oct, Nov, Dec, Jan, Mar, May & July, Aug, Feb & Apr \\
\hline 1992 & June, Dec, Jan, Feb, Mar, Apr & July, Aug, Sep, Nov & Oct, May \\
\hline 1993 & Oct, Nov, Dec, Jan, Feb, Apr, May & June, July, Aug & Sep, Mar \\
\hline 1994 & Oct, Nov, Dec, Feb, Mar, Apr, May & June, July, Aug, Sep & Jan \\
\hline 1995 & June, Oct, Nov, Feb, May & July, Aug, Sep, Apr & Dec, Jan, Mar \\
\hline 1996 & Oct, Nov, Dec, Feb, Apr & June, July, Aug, Sep, Jan, Mar, May & \\
\hline 1997 & Feb, Mar & June, July, Aug, Sep, Jan, May & Oct, Nov, Dec, Apr \\
\hline 1998 & Aug, Nov, Dec, Jan, Feb, May & June, July, Sep, Oct & Mar, Apr \\
\hline 1999 & Aug, Nov, Dec, Jan, Mar, Apr, May & June, July, Oct & Sep, Feb \\
\hline 2000 & June, Aug, Oct, Nov, Dec, Jan, Feb, Mar, Apr & July, Sep & May \\
\hline 2001 & Sep, Oct, Nov, Dec, Jan, Feb, Mar & June, July, Aug, Apr & May \\
\hline 2002 & July, Oct, Nov, Dec, Jan, Mar, Apr, May & June, Aug, Sep & Feb \\
\hline 2003 & Oct, Nov, Jan, Mar, Apr & June, July, Aug, Sep, Dec Feb, May & \\
\hline 2004 & Sep, Nov, Dec, Feb, Mar, Apr, May & June, July, Aug, Oct, Jan & \\
\hline 2005 & Aug, Oct, Nov, Dec, Jan, Feb, May & June, July, Sep, Apr & Mar \\
\hline 2006 & Nov, Dec, Jan, Feb, Apr & June, July, Sep, Oct, May & Aug, Mar \\
\hline 2007 & Aug, Oct, Nov, Jan, Mar, Apr, May & June, July, Sep, Dec, Feb & \\
\hline 2008 & Sep, Oct, Dec, Jan, Feb, Mar, May & June, July, Aug, Apr & Nov \\
\hline 2009 & June, Aug, Dec, Jan, Feb, Mar, Apr, May & July, Sep, Oct, Nov & \\
\hline 2010 & July, Aug, Oct, Dec, Feb, Mar, Apr, May & June, Sep, Jan & Nov \\
\hline 2011 & Oct, Nov, Dec, Feb, Mar, Apr & June, July, Aug, Sep, May & Jan \\
\hline
\end{tabular}

ment. This information may be useful for making rainwater harvesting system at household level at farmer's field or on common land for irrigation planning and

$$
\begin{aligned}
\text { Area } & =1 \mathrm{ha} \\
& =100 \times 100 \mathrm{~m}
\end{aligned}
$$

Rainfall recorded $=921.5 \mathrm{~mm}$

$$
=92.15 \mathrm{~cm}
$$

Volume of rainfall $=$ Area of field $\times$ Depth of rainfall

$$
\begin{aligned}
& =1 \text { ha } \times 92.15 \mathrm{~cm} \\
& =100 \mathrm{~m} \times 100 \mathrm{~m} \times 92.15 \mathrm{~cm} \\
& =9215 \mathrm{~m}^{3} \\
& =9215000 \text { litres }
\end{aligned}
$$

their management in this region.

Storage of rainwater: Based on study for the period under context (1980-2011), it is manifested that the long term average rainfall $921.5 \mathrm{~mm}$ in the region. The rain water falling on the ground can be quantified on the hectare basis as under:

Assume that 10 per cent of rain water is lost as runoff losses. It means available water which can be stored $=$ $9215-9215 \times(10 / 100)=8293.5 \mathrm{~m}^{3}$. Average annual rainfall in the region is $921.5 \mathrm{~mm}$; even then water scarcity is encountered even with the cessation of rainfall. As per the availability of the land and rainfall, at least 50 per cent rainwater can be stored at the farm level to fulfill the irrigation requirements of the crops. Accordingly, the proposed design has been depicted through Fig. 2. The design of trapezoidal shape pond to store at least 50 per cent water has been hypothesized as under:

Bottom width $=20 \mathrm{~m}$, Bottom length $=30 \mathrm{~m}$, Depth $=5 \mathrm{~m}$ and Side slope $=1: 1$

Volume of pond:

$$
\begin{aligned}
V & =\frac{(A+4 B+C) \times D}{6} \\
& =(1200+3500+600) \times(5 / 6) \\
& =4416 \mathrm{~m}^{3}
\end{aligned}
$$




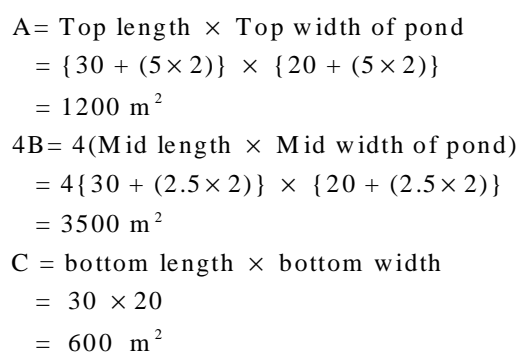

where,

If constructed, the pond can store approximately $4416 \mathrm{~m}^{3} \approx 4416000$ litres of rains water (assuming no seepage). This amount of water may be useful for irrigation purpose. Singh (2011) quantified the quantity of water and highlighted the utility of water management. Irrigation planning for crop production: Excessive use and poor management of rain water has had, in some cases, detrimental effects on soil quality, causing whole areas to be taken out of production or requiring the construction of expensive drainage works. Rainfall is, in most parts of the world, for at least part of the year, insufficient to grow crops and food production is heavily affected by the annual variations in precipitation. Irrigation is an obvious option to increase and stabilize crop production. Defining strategies in irrigation planning and management of stored rain water for crop production is very important for Indian agriculture. The effective use of rain water for crop production will be one of the main requirements. Crop water use need to be optimized through a more effective use and conservation of rainwater and by measures to increase crop production. Traditional cropping systems and genetic characteristics of the local crop types are adapted to minimize drought risks and to maintain minimum production levels under erratic rainfall supplies.

The introduction of better yielding varieties combined with a more secured water supply through improved water conservation will increase crop production per unit of water and also the introduction of measures to conserve rain water irrigation combined with appropriate plant nutrition and cultural practices, will lead to increased production levels per unit of water with equal water availability. Examples of practical procedures to assess crop water use and crop production levels under restricted rainfall and water supply are discussed (Steduto et al., 2012 and Aiken et al., 2013) by estimating crop evapotranspiration. The introduction of computerized procedures linked to digital data bases will greatly enhance the use of appropriate planning and management techniques for water use in irrigated and rainfed agriculture (Smith, 2000).

Water use for crop production is depending on the interaction of climatic parameters that determine crop evapotranspiration and water supply from rain. The analysis of climatic information for crop water use is therefore a key element in developing appropriate strategies to face the global water crisis and looming food shortages. A better understanding of the intricate interactions between climate, water and crop growth needs to be a priority area in agrometeorological studies.

\section{Conclusion}

It was concluded from the analysis that the rainfall of the study area is having decreasing trend year after year. These changes are manifested at monthly, seasonal and annual levels. It highlights less water availability for crops and natural vegetation. For most of the years, annual rainfall was adequate for all rounds the year crop production. Provided the water is stored there cannot be sustainable crop production. Options to increase water use efficiency include a more effective use and conservation of rain water as well as an increase in production per unit of water used.

\section{ACK NOWLEDGEMENTS}

The authors are grateful to the Department of Water Resource, Government of Rajasthan, Sinchai Bhawan, Jaipur for making the data available for the study.

\section{REFERENCES}

Aiken, R.M., O’Brien, D.M., Olson, B.L. and Murray, L. (2013). Replacing fallow with continuous cropping reduces crop water productivity of semiarid wheat. Agronomy J ournal, 105(1):199-207.

Basistha, A., Goel, N.K. Arya, D.S. and Gangwar, S.K. (2007). Spatial pattern of trends in Indian sub-divisional rainfall. J alvigyan Sameeksha, 22:47-57.

Bhakar, S.R., Iqbal, M., Devanda, M., Chhajed, N. and Bansal, A.K. (2008). Probability analysis of rainfall at Kota. Indian J ournal of Agricultural Research, 42:201206.

Bora, P.K., Karmakar, R.M., Kurmi, K. and Debnath, M.C. (2008). Rainfall analysis for rought investigation in Central Brahmaputra Valley of Assam. Journal of Agrometeorology, (Special Issue) 2:479-482.

Kendall, M.G. (1975). Rank correlation methods. Charles Griffin, London, UK.

Mann, H.B. (1945). Nonparametric tests against trend. Econometrica, 13:245-259.

Momin, U., Kulkarni, P.S., Horaginamani, S.M., Ravichandran, M., Patel, A.M. and Kousar, H. (2011). Rainfall analysis for crop planning in semi arid region of Southern Telangana, India. Indian Journal of Natural Science, 1(7): 450-458.

Murty, J.V.S. (1994). Water. In: Watershed management in India, Wiley Eastern Limited, New Delhi, pp. 63.

Rai, S. and Singh, K.A. (2009). Rainfall variability and probability for crop planning at Madhepura in Bihar. J ournal of Agrometeorology, 11: 42-46.

Sen, P.K. (1968). Estimates of the regression coefficient based on Kendall's tau. J ournal of the American Statistical Association, 63: 1379-1389.

Sharma, H.C., Chauhan, H.S. and Ram, S. (1979). Probability analysis of rainfall for crop planning. J ournal of Agricultural Engineering, 16(3): 87-92.

Sheoran, P., Singh, S. and Sardana, V. (2008). Rainfall analysis and crop planning in lower Shiwalik foothills of Punjab. Journal of Agrometeorology, 10: 193-197.

Singh, B., Rajpurohit, D., Vasishth, A. and Singh, J. (2012). Probability analysis for estimation of annual one day maximum rainfall of Jhalarapatan area of Rajasthan. 
Plant Archives, 12(2):1093-1100.

Singh, B. and Sharma, M.K. (2003). A study of pattern of rainfall of crop research station-Masodha (U.P.). Mausam, 54 (2): 552-556.

Singh, J. (2011). Water management. In: Basic Horticulture. Kalyani Publishers, Ludhiana, pp. 153-165.

Singh, P.K., Rathore, L.S., Singh, K.K. and Baxla, A.K. (2009). Rainfall characteristics of North West alluvial plain zone of Bihar. J ournal of Agrometeorology, 11:37 -41 .

Singh, V. and Dev, P. (2012). 50 year rainfall data analysis and future trend in Saharanpur region. M ausam, 63 (1):55-64.

Smith, M. (2000). The application of climatic data for planning and management of sustainable rainfed and irrigated crop production. Agricultural and Forest M eteorology, 103:99-108.

Sneyers, R. (1992). Use and mis-use of statistical methods for detection of climatic change. Climate Change Detection Project. Report on the Informal Planning Meeting on Statistical Procedures for Climate Change Detection, WCDMP, 20: J76-J81.

Solanki, N.S. and Singh, A.K. (2009). Rainfall analysis for crop planning in the Humid Southern Plains of Rajasthan. J ournal of Water M anagement, 17(2): 2009.

Srivastava, R.K. and Shukla, R.M. (2009). Probabilistic approach of rainfall data for irrigation planning. Research on Crops, 10(2): 448-452.

Steduto, P., Hsiao, T.C., Fereres, E. and Raes, D. (2012). Crop yield response to water. FAO Irrigation and Drainage Paper No. 66. Rome, FAO.

Upadhyay, V.K. and Upadhyay, S.P. (2009). Statistical analysis of rainfall distribution and trend of rainfall anomalies district-wise during monsoon period over eastern Uttar Pradesh. Research on Crops, 10(2): 453-460.

Yue, S. Pilon, P. and Cavadias, G. (2002). Power of the Mann-Kendall and Spearman's Rho tests for detecting monotonic trends in hydrologic series. Journal of Hydrology, 259:254-271. 